\section{TRENDS IN INTERNATIONAL ARMS TRANSFERS, 2018}

PIETER D. WEZEMAN, AUDE FLEURANT, ALEXANDRA KUIMOVA, NAN TIAN AND SIEMON T. WEZEMAN

The volume of international transfers of major arms in 2014-18 was 7.8 per cent higher than in 2009-13 and 23 per cent higher than in 2004-2008 (see figure 1). The five largest exporters in 2014-18 were the United States, Russia, France, Germany and China (see table 1). The five largest importers were Saudi Arabia, India, Egypt, Australia and Algeria (see table 2, page 6).

The flow of arms to the Middle East increased by 87 per cent between 2009-13 and 2014-18, while there was a decrease in flows to all other regions: Africa, the Americas, Asia and Oceania, and Europe.

From 11 March 2019 the freely accessible SIPRI Arms Transfers Database includes updated data on arms transfers for 1950-2018. ${ }^{1}$ Based on the new data, this Fact Sheet highlights global and regional trends and selected issues related to arms transfers.

${ }^{1}$ For further detail on the SIPRI Arms Transfers Database see page 12.

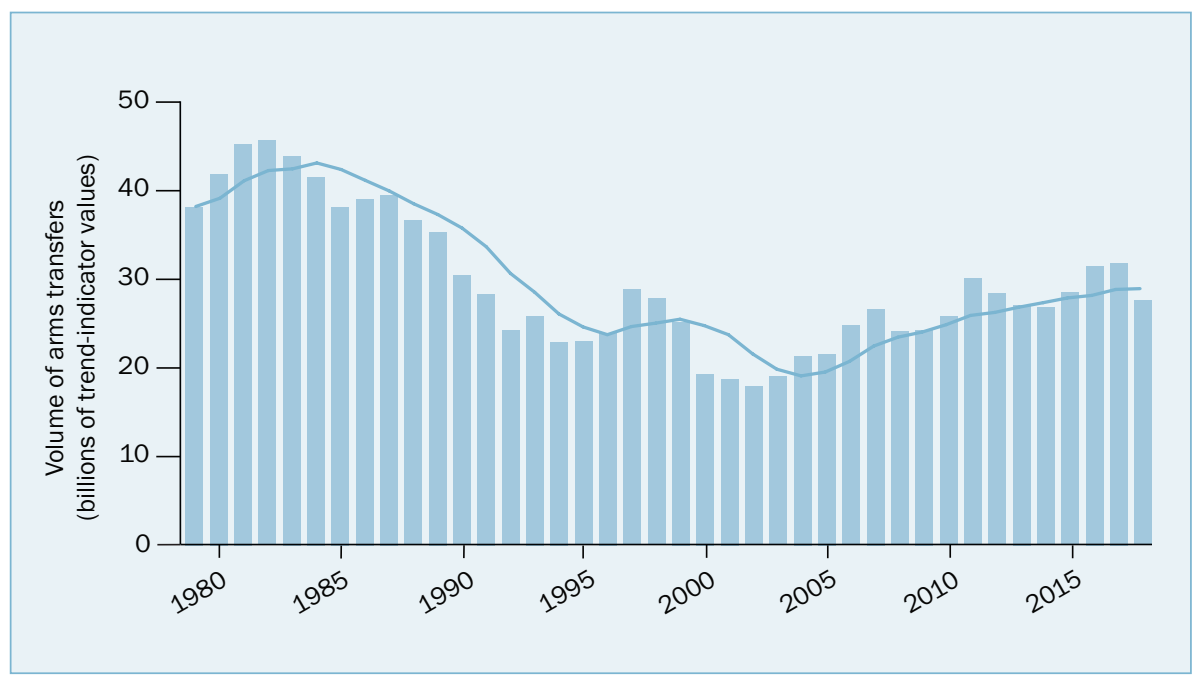

Figure 1. The trend in international transfers of major arms, 1979-2018

Note: The bar graph shows annual totals and the line graph shows the 5-year moving average (each data point in the line graph represents an average for the preceding 5 -year period). The SIPRI trend-indicator value (TIV) is a measure of the volume of international transfers of major arms. The method used to calculate the SIPRI TIV is described on the Arms Transfers Database web page.

Source: SIPRI Arms Transfers Database, Mar. 2019.

\section{KEY FACTS}

- The volume of international transfers of major arms has grown steadily since 2003 . In 2014-18 the volume was 7.8 per cent higher than in 2009-13 and 23 per cent higher than in 2004-2008.

- The five largest exporters in 2014-18 were the United States, Russia, France, Germany and China. Together, they accounted for 75 per cent of the total volume of arms exports in 2014-18. - US exports accounted for 36 per cent of the global total in 2014-18. US arms exports in 2014-18 grew by 29 per cent compared with 2009-13.

- Russian arms exports decreased by 17 per cent between 2009-13 and 2014-18.

- French, German and Chinese arms exports in 2014-18 were higher than in 2009-13, with respective increases of 43,13 and 2.7 per cent.

- The five largest importers in 2014-18-Saudi Arabia, India, Egypt, Australia and Algeriatogether received 35 per cent of all arms imports.

- The main recipient region in 2014-18 was Asia and Oceania (accounting for 40 per cent of global imports), followed by the Middle East (35 per cent), Europe (11 per cent), Africa (7.8 per cent) and the Americas (6.2 per cent).

- Between 2009-13 and 2014-18 arms imports by states in the Middle East increased by 87 per cent. By contrast, overall imports decreased in the Americas (-36 per cent), Europe ( -13 per cent), Asia and Oceania ( -6.7 per cent) and Africa (-6.5 per cent). 
Table 1. The 25 largest exporters of major arms and their main clients, 2014-18

Note: Percentages below 10 are rounded to 1 decimal place; percentages over 10 are rounded to whole numbers.

\begin{tabular}{|c|c|c|c|c|c|c|c|}
\hline & \multirow[b]{2}{*}{ Exporter } & \multicolumn{2}{|c|}{$\begin{array}{l}\text { Share of } \\
\text { arms exports (\%) }\end{array}$} & \multirow{2}{*}{$\begin{array}{l}\text { Per cent } \\
\text { change from } \\
2009-13 \text { to } \\
2014-18^{a}\end{array}$} & \multicolumn{3}{|c|}{$\begin{array}{l}\text { Main clients (share of exporter's total exports, \%), } \\
2014-18\end{array}$} \\
\hline & & 2014-18 & 2009-13 & & 1 st & 2nd & $3 r d$ \\
\hline 1 & United States & 36 & 30 & 29 & Saudi Arabia (22) & Australia (7.7) & UAE (6.7) \\
\hline 2 & Russia & 21 & 27 & -17 & India $(27)$ & China (14) & Algeria (14) \\
\hline 3 & France & 6.8 & 5.1 & 43 & Egypt (28) & India (9.8) & Saudi Arabia (7.4) \\
\hline 4 & Germany & 6.4 & 6.1 & 13 & South Korea (19) & Greece (10) & Israel (8.3) \\
\hline 5 & China & 5.2 & 5.5 & 2.7 & Pakistan (37) & Bangladesh (16) & Algeria (11) \\
\hline 6 & United Kingdom & 4.2 & 4.3 & 5.9 & Saudi Arabia (44) & Oman (15) & Indonesia (11) \\
\hline 7 & Spain & 3.2 & 2.9 & 20 & Australia (42) & Turkey (13) & Saudi Arabia (8.3) \\
\hline 8 & Israel & 3.1 & 2.1 & 60 & India (46) & Azerbaijan (17) & Viet Nam (8.5) \\
\hline 9 & Italy & 2.3 & 2.7 & -6.7 & Turkey (15) & Algeria (9.1) & Israel (7.6) \\
\hline 10 & Netherlands & 2.1 & 1.9 & 16 & Jordan (15) & Indonesia (15) & USA (11) \\
\hline 11 & South Korea & 1.8 & 1.0 & 94 & Indonesia (17) & Iraq (17) & UK (15) \\
\hline 12 & Ukraine & 1.3 & 2.7 & -47 & China (27) & Russia (23) & Thailand (14) \\
\hline 13 & Switzerland & 1.0 & 0.9 & 20 & Saudi Arabia (19) & China (18) & Indonesia (9.3) \\
\hline 14 & Turkey & 1.0 & 0.4 & 170 & UAE (30) & Turkmenistan (23) & Saudi Arabia (10) \\
\hline 15 & Sweden & 0.7 & 1.9 & -62 & Saudi Arabia (16) & $\mathrm{UAE}(14)$ & Algeria (10) \\
\hline 16 & Canada & 0.6 & 0.9 & -33 & Saudi Arabia (22) & India (13) & UAE (7.6) \\
\hline 17 & Norway & 0.5 & 0.6 & -12 & Oman (28) & Finland (23) & USA (21) \\
\hline 18 & UAE & 0.3 & 0.2 & 103 & Egypt (41) & Jordan (10) & Yemen (7.6) \\
\hline 19 & Czechia & 0.3 & 0.1 & 472 & Iraq $(40)$ & USA (17) & Viet Nam (9.9) \\
\hline 20 & Belarus & 0.3 & 0.5 & -26 & Viet Nam (37) & Sudan (18) & Myanmar (12) \\
\hline 21 & Australia & 0.3 & 0.3 & 3.9 & USA (53) & Indonesia (25) & Oman (8.8) \\
\hline 22 & South Africa & 0.3 & 0.5 & -35 & USA $(21)$ & UAE (21) & India (9.8) \\
\hline 23 & Brazil & 0.2 & 0.2 & 21 & Afghanistan (32) & Indonesia (25) & Lebanon (9.1) \\
\hline 24 & Finland & 0.2 & 0.2 & -9.1 & Poland (56) & $\mathrm{UK}(7.1)$ & Sweden (6.7) \\
\hline 25 & Portugal $^{b}$ & 0.2 & 0.0 & 457 & Romania (89) & Belgium (7.0) & Uruguay (2.7) \\
\hline
\end{tabular}

UAE $=$ United Arab Emirates.

${ }^{a}$ Figures show the change in volume of the total arms exports per exporter between the 2 periods.

${ }^{b}$ For Portugal, the percentage change from $2009-13$ to $2014-18$ is $0.03 \%$.

Source: SIPRI Arms Transfers Database, Mar. 2019.

\section{THE EXPORTERS, 2014-18}

SIPRI has identified 67 countries as exporters of major arms in 2014-18. The five largest suppliers of arms during that period-the USA, Russia, France, Germany and China-accounted for 75 per cent of all arms exports (see figure 2 and table 1). The top five in 2014-18 were the same as in 2009-13 but their combined total exports of major arms were 10 per cent higher. In 2014-18 there were significant increases in US, French and German arms exports, while Chinese exports rose marginally and Russian exports decreased (see figure 3). The top 25 arms exporters accounted for 99 per cent of the world's major arms exports in 2014-18, with a total of 87 per cent coming from states in North America and Europe (see table 1). 


\section{The United States}

The USA was the top arms exporter in 2014-18 and 2009-13. Its exports of major arms grew by 29 per cent between the two periods and its share of total global exports rose from 30 per cent to 36 per cent. In terms of deliveries of major arms, the gap between the USA and Russia-the second largest exporter-continued to widen: in 2009-13 US exports of major arms were 12 per cent higher than those of Russia, whereas in 2014-18 they were 75 per cent higher.

The Middle East accounted for 52 per cent of total US arms exports in 2014-18. US arms exports to the region increased by 134 per cent between 2009-13 and 2014-18. US arms exports to Africa also rose, by 26 per cent, while there were decreases in arms exports to Asia and Oceania (-16 per cent), Europe (-8.1 per cent) and the Americas ( -4.8 per cent).

The USA delivered major arms to at least 98 states in 2014-18, a far higher number of export destinations than any other supplier. Saudi Arabia was the main recipient and accounted for 22 per cent of US arms exports, compared with 4.9 per cent in 2009-13. In 2014-18 US arms exports to Saudi Arabia were 2.8 times higher than those to the second largest recipient of US arms-Australia.

Between 2009-13 and 2014-18 there were also large increases in US arms exports to Israel, Taiwan and Qatar (by largest increase). The largest decreases were to Singapore, South Korea and Pakistan (by largest decrease).

Aircraft accounted for 53 per cent of US major arms exports in 2014-18, which included the delivery of a total of 255 advanced combat aircraft to 14 countries. Based on the volume of existing orders, it is possible to conclude that combat aircraft will continue to be the main US arms export for the foreseeable future. In 2018, for example, Japan and Belgium decided to procure 105 and 34 F-35 combat aircraft, respectively, while Slovakia ordered $14 \mathrm{~F}-16 \mathrm{Vs}$. By the end of 2018, a total of 891 advanced combat aircraft were on order from the USA.

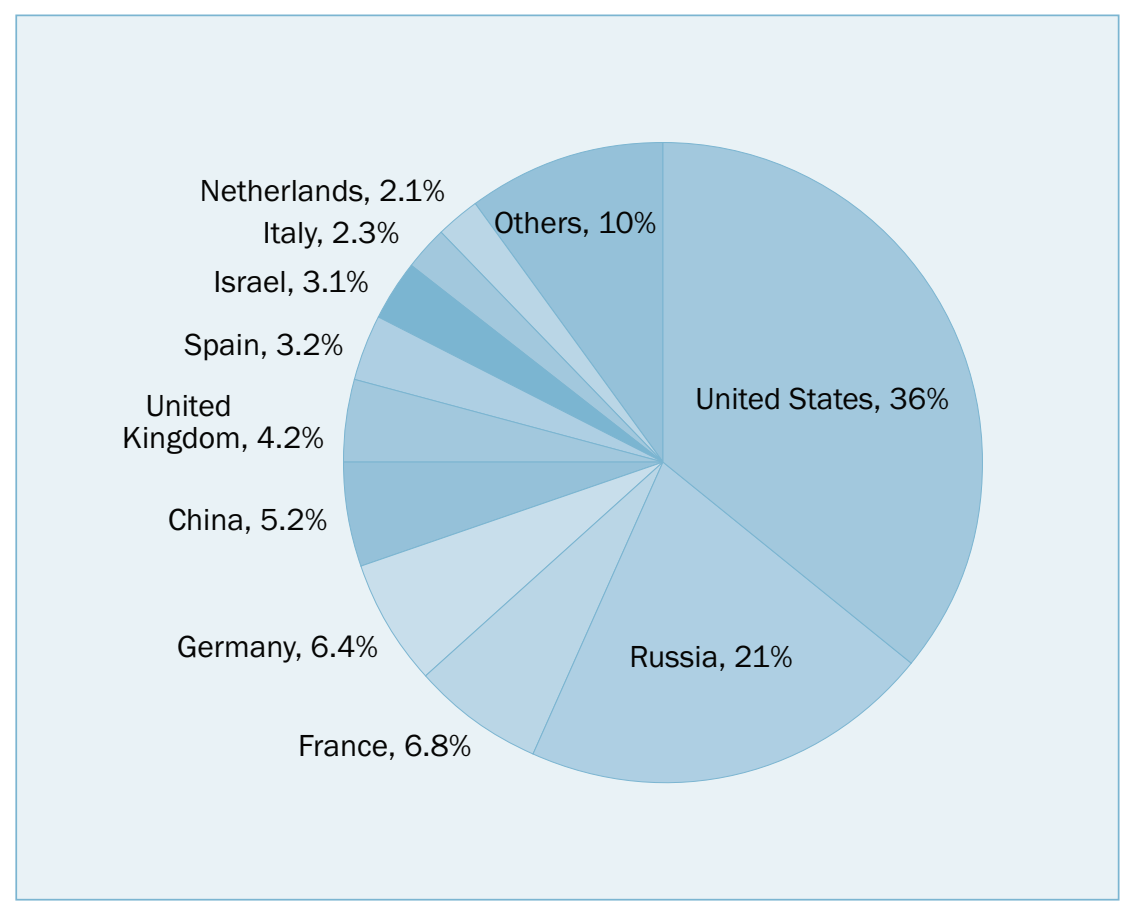

Figure 2. Global share of major arms exports by the 10 largest exporters, 2014-18

Source: SIPRI Arms Transfers Database, Mar. 2019.

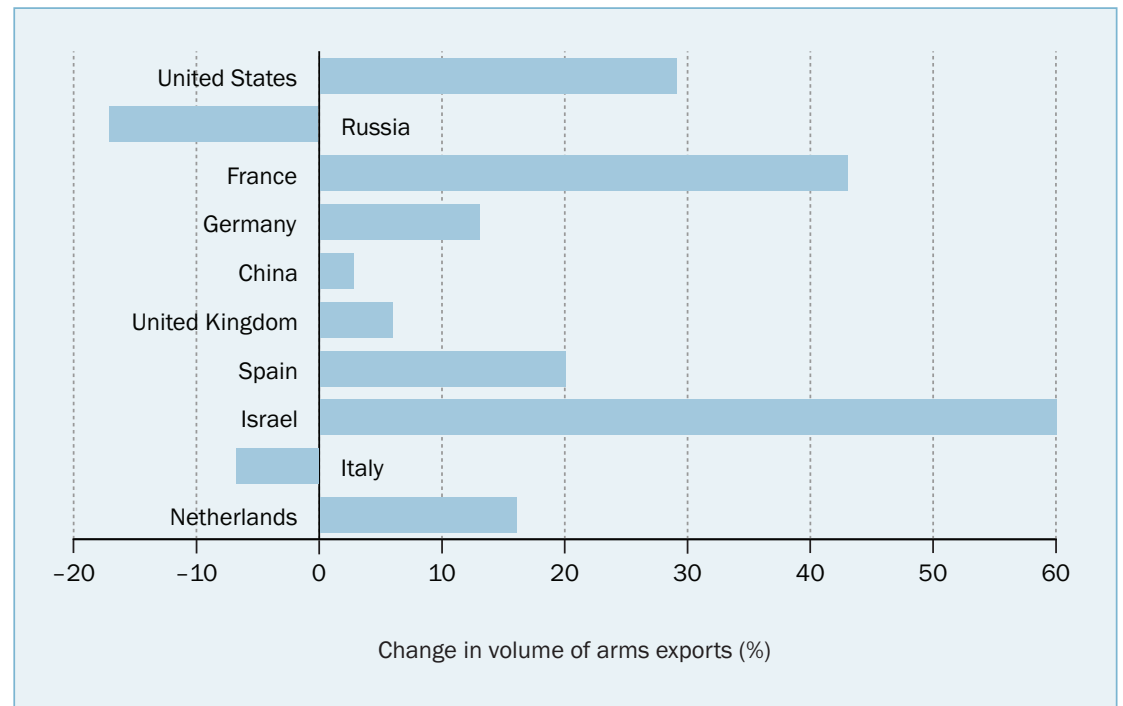

Figure 3. Changes in volume of major arms exports since 2009-13 by the 10 largest exporters in 2014-18

Source: SIPRI Arms Transfers Database, Mar. 2019. 
Box 1. Transfers of ballistic missile defence systems

Concerns about the proliferation of ballistic missiles in many regions have led to an increase over the past 10 years in the number of countries importing ballistic missile defence systems. The number of suppliers has also risen during that period.

\section{The United States}

In 1999-2008 the United States was the only exporter of ballistic missile defence systems. It delivered ship-based AEGIS systems with SM-3 missiles to Japan and land-based Patriot PAC-3 systems to Germany, Japan and the Netherlands. In 2009-18 the USA delivered Patriot PAC-3 systems to Kuwait, Qatar, Saudi Arabia, South Korea, Taiwan and the United Arab Emirates (UAE). It also delivered land-based THAAD systems, which are more capable than the Patriot PAC-3, to the UAE. In 2018 Poland, Romania and Sweden ordered Patriot PAC-3 systems, Saudi Arabia ordered the THAAD system, and Japan ordered additional SM-3 missiles and decided to procure land-based AEGIS Ashore systems.

\section{Other suppliers}

In 2016 Israel delivered a land-based Barak- 8 system to Azerbaijan and started deliveries of ship-based Barak- 8 systems to India. India ordered the land-based version in 2009, with deliveries to start in 2020. France delivered land-based SAMP/T systems to Singapore in 2017-18. In 2018 Russia delivered S-400 systems to China. It received orders for the S- 400 from Turkey in 2017 and India in 2018.

Guided missiles accounted for 19 per cent of US major arms exports in 2014-18. These exports included the delivery of 400 cruise missiles and 124 ballistic missiles-both types with a range of between 250 and 400 kilometres. The USA also exported around 36500 anti-tank missiles and 53500 guided bombs. As in previous years, in 2014-18 the USA remained the primary exporter of ballistic missile defence systems (see box 1).

Although the USA is the world's largest arms exporter and has the capability to produce all types of arms, in 2014-18 it was still the 16th largest arms importer globally. However, its arms imports fell by 47 per cent between 2009-13 and 2014-18.

\section{Russia}

Russian exports of major arms decreased by 17 per cent between 2009-13 and 2014-18. The fall was partly due to general reductions in Indian and Venezuelan arms imports-two countries that have been among the main recipients of Russian arms exports in previous years. Although India remained the chief recipient of Russian arms in 2014-18, Russian arms exports to India fell by 42 per cent between 2014-18 and 2009-13. Arms exports to Venezuela, which was the fifth largest recipient of Russian arms in 2009-13, decreased by 96 per cent between the two periods.

In 2014-18 Russia delivered major arms to 48 states. A total of 55 per cent of its arms exports went to its three main recipients: India, China and Algeria (see table 1). At the regional level, states in Asia and Oceania accounted for 60 per cent of Russian arms exports in 2014-18, Africa for 17 per cent, the Middle East for 16 per cent, Europe for 5.8 per cent and the Americas for 1.4 per cent.

Russian exports of major arms to the Middle East increased by 19 per cent between 2009-13 and 2014-18. In 2014-18 Egypt and Iraq were the main recipients of Russian arms exports to the Middle East, accounting, respectively, for 46 and 36 per cent of Russian arms exports to the region. Deliveries to Iraq increased by 780 per cent between 2009-13 and 2014-18, while those to Egypt rose by 150 per cent. 


\section{The European Union and West European countries}

The combined arms exports by European Union (EU) member states accounted for 27 per cent of the global total in 2014-18. The top five West European arms exporters-France, Germany, the United Kingdom, Spain and Italy-together accounted for 23 per cent of the world's arms exports in 2014-18, compared with 21 per cent in 2009-13. For four of these countries, the region that accounted for the highest growth in exports was the Middle East. French arms exports to the region rose by 261 per cent between 2009-13 and 2014-18, while German, Italian and British exports grew by 125 , 75 and 30 per cent, respectively. Asia and Oceania accounted for the highest increase (by 215 per cent) in Spanish arms exports.

France's arms exports rose by 43 per cent between 2009-13 and 2014-18. A total of 44 per cent of French arms exports went to the Middle East, 29 per cent to Asia and Oceania, 9.5 per cent to other states in Europe, 8.7 per cent to the Americas and 8.5 per cent to Africa. France delivered major arms to 78 states in 2014-18. Egypt was by far the largest recipient of French arms during that period, followed by India (see table 1). Neither country was a major importer of French arms in 2009-13.

Germany's exports of major arms increased by 13 per cent between 2009-13 and 2014-18. In 2014-18 a total of 30 per cent of German arms exports went to Asia and Oceania, 27 per cent to other states in Europe, 25 per cent to the Middle East, 11 per cent to the Americas and 7.3 per cent to Africa. Ships, in particular submarines, accounted for 52 per cent of German arms exports in 2014-18.

Between 2009-13 and 2014-18 British arms exports increased by 5.9 per cent. In 2014-18 a total of 59 per cent of British arms exports went to the Middle East, the vast bulk of which was made up of deliveries of combat aircraft to Saudi Arabia and Oman.

\section{China}

Whereas Chinese arms exports rose by 195 per cent between 2004-2008 and 2009-13, they increased by only 2.7 per cent between $2009-13$ and 2014-18. In 2014-18 Asia and Oceania accounted for 70 per cent of Chinese arms exports, Africa for 20 per cent and the Middle East for 6.1 per cent.

The number of countries to which China delivers major arms has grown significantly over the past few years. In 2014-18 China delivered major arms to 53 countries, compared with 41 in 2009-13 and 32 in 2004-2008. Pakistan was the main recipient (37 per cent) in 2014-18, as it has been for all five-year periods since 1991. China supplied relatively small volumes of major arms to a wide variety of countries: 39 of the 53 recipients in 2014-18 each accounted for less than 1 per cent of total Chinese arms exports.

China's arms exports are limited by the fact that many countries-including 4 of the top 10 arms importers in 2014-18 (India, Australia, South Korea and Viet Nam) -will not procure Chinese arms for political reasons. Nonetheless, improvements in Chinese military technology have opened up opportunities for arms export growth, including exports to new customers. In 2014-18 China became the largest exporter in the niche market of unmanned combat aerial vehicles (UCAVs), with states in the Middle East 
Table 2. The 40 largest importers of major arms and their main suppliers, 2014-18

Note: Percentages below 10 are rounded to 1 decimal place; percentages over 10 are rounded to whole numbers.

\begin{tabular}{|c|c|c|c|c|c|c|c|}
\hline & \multirow[b]{2}{*}{ Importer } & \multicolumn{2}{|c|}{$\begin{array}{l}\text { Share of } \\
\text { arms imports (\%) }\end{array}$} & \multirow{2}{*}{$\begin{array}{l}\text { Per cent } \\
\text { change from } \\
2009-13 \text { to } \\
2014-18^{a}\end{array}$} & \multicolumn{3}{|c|}{$\begin{array}{l}\text { Main suppliers (share of importer's total imports, \%), } \\
\text { 2014-18 }\end{array}$} \\
\hline & & 2014-18 & 2009-13 & & 1 st & 2nd & $3 \mathrm{rd}$ \\
\hline 1 & Saudi Arabia & 12 & 4.3 & 192 & USA (68) & UK (16) & France (4.3) \\
\hline 2 & India & 9.5 & 13 & -24 & Russia (58) & Israel (15) & USA (12) \\
\hline 3 & Egypt & 5.1 & 1.8 & 206 & France (37) & Russia (30) & USA (19) \\
\hline 4 & Australia & 4.6 & 3.6 & 37 & USA (60) & Spain (29) & France $(5.0)$ \\
\hline 5 & Algeria & 4.4 & 3.1 & 55 & Russia (66) & China (13) & Germany (10) \\
\hline 6 & China & 4.2 & 4.8 & -7.0 & Russia (70) & France (10) & Ukraine (8.6) \\
\hline 7 & UAE & 3.7 & 4.2 & -5.8 & USA (64) & France (10) & Turkey (7.8) \\
\hline 8 & Iraq & 3.7 & 1.6 & 139 & USA (47) & Russia (33) & South Korea (8.0) \\
\hline 9 & South Korea & 3.1 & 3.6 & -8.6 & USA (51) & Germany (39) & UK (3.0) \\
\hline 10 & Viet Nam & 2.9 & 1.8 & 78 & Russia (78) & Israel (9.1) & Belarus (4.1) \\
\hline 11 & Pakistan & 2.7 & 4.8 & -39 & China (70) & USA (8.9) & Russia (6.0) \\
\hline 12 & Indonesia & 2.5 & 1.4 & 86 & UK (19) & USA (18) & Netherlands (13) \\
\hline 13 & Turkey & 2.3 & 3.2 & -21 & USA $(60)$ & Spain (17) & Italy (15) \\
\hline 14 & Qatar & 2.0 & 0.7 & 225 & USA (65) & Germany (15) & France (7.4) \\
\hline 15 & Israel & 2.0 & 0.5 & 354 & USA (64) & Germany (27) & Italy (8.9) \\
\hline 16 & United States & 1.8 & 3.7 & -47 & Germany (22) & Netherlands (13) & France (11) \\
\hline 17 & Taiwan & 1.7 & 1.0 & 83 & USA (100) & Germany (0.2) & Italy $(0.1)$ \\
\hline 18 & Oman & 1.6 & 0.6 & 213 & UK (39) & USA (30) & Norway (8.5) \\
\hline 19 & United Kingdom & 1.6 & 1.7 & 2.3 & USA (71) & South Korea (17) & Germany (4.5) \\
\hline 20 & Italy & 1.5 & 0.6 & 162 & USA (59) & Germany (26) & Israel (7.5) \\
\hline 21 & Japan & 1.4 & 1.3 & 15 & USA (95) & $\mathrm{UK}(3.1)$ & Sweden (1.5) \\
\hline 22 & Singapore & 1.3 & 3.7 & -63 & USA (46) & France (21) & Spain (11) \\
\hline 23 & Azerbaijan & 1.3 & 1.2 & 15 & Russia (51) & Israel (43) & Turkey (2.8) \\
\hline 24 & Morocco & 1.2 & 2.0 & -35 & USA (62) & France (36) & Italy (0.6) \\
\hline 25 & Bangladesh & 1.2 & 0.7 & 75 & China (70) & Russia (18) & USA (3.2) \\
\hline 26 & Canada & 1.0 & 0.8 & 42 & USA (63) & Netherlands (16) & Germany (6.9) \\
\hline 27 & Thailand & 1.0 & 0.7 & 46 & South Korea (20) & Ukraine (18) & China (18) \\
\hline 28 & Greece & 1.0 & 1.5 & -30 & Germany (67) & USA (20) & France (8.4) \\
\hline 29 & Kuwait & 1.0 & 0.2 & 348 & USA (87) & Russia (3.4) & Switzerland (2.9) \\
\hline 30 & Kazakhstan & 0.9 & 0.3 & 232 & Russia (84) & Spain (5.5) & France (3.0) \\
\hline 31 & Jordan & 0.9 & 0.6 & 61 & Netherlands (37) & USA (30) & Italy (5.8) \\
\hline 32 & Norway & 0.8 & 1.1 & -22 & USA $(76)$ & South Korea (9.3) & Italy (6.2) \\
\hline 33 & Afghanistan & 0.8 & 1.6 & -48 & USA (66) & Russia (18) & Brazil (10) \\
\hline 34 & Mexico & 0.7 & 0.5 & 40 & USA (63) & France (9.4) & Netherlands (8.9) \\
\hline 35 & Brazil & 0.6 & 1.0 & -28 & France (26) & USA (17) & UK (15) \\
\hline 36 & Myanmar & 0.6 & 1.1 & -40 & China (61) & Russia (20) & Belarus (6.5) \\
\hline 37 & Finland & 0.6 & 0.4 & 64 & USA (37) & Netherlands (19) & Norway (19) \\
\hline 38 & Poland & 0.6 & 0.6 & 2.5 & Germany (28) & Finland (20) & Italy (16) \\
\hline 39 & Turkmenistan & 0.5 & 0.4 & 59 & Turkey (43) & China (31) & Russia (13) \\
\hline 40 & Peru & 0.5 & 0.1 & 303 & South Korea (34) & Russia (22) & Italy (14) \\
\hline
\end{tabular}

$\mathrm{UAE}=$ United Arab Emirates.

${ }^{a}$ Figures show the change in volume of the total arms imports per importer between the 2 periods.

Source: SIPRI Arms Transfers Database, Mar. 2019. 
among the main recipients (see box 2, page 10).

\section{Other arms exporters}

Between 2009-13 and 2014-18 South Korean and Turkish arms exports increased by 94 and 170 per cent, respectively. Both countries have adopted policies aimed at increasing their arms exports. However, both remained outside the top 10 largest arms exporters in 2014-18: South Korea was 11th and Turkey was 14th.

Generally speaking, a policy of ambitious arms export growth is difficult to implement in the long term, particularly as recent history has shown that arms exports by smaller exporters can fluctuate significantly. For example, Sweden was the 15th largest arms exporter in 2014-18, having been the 7th largest in 1999-2003. Similarly,

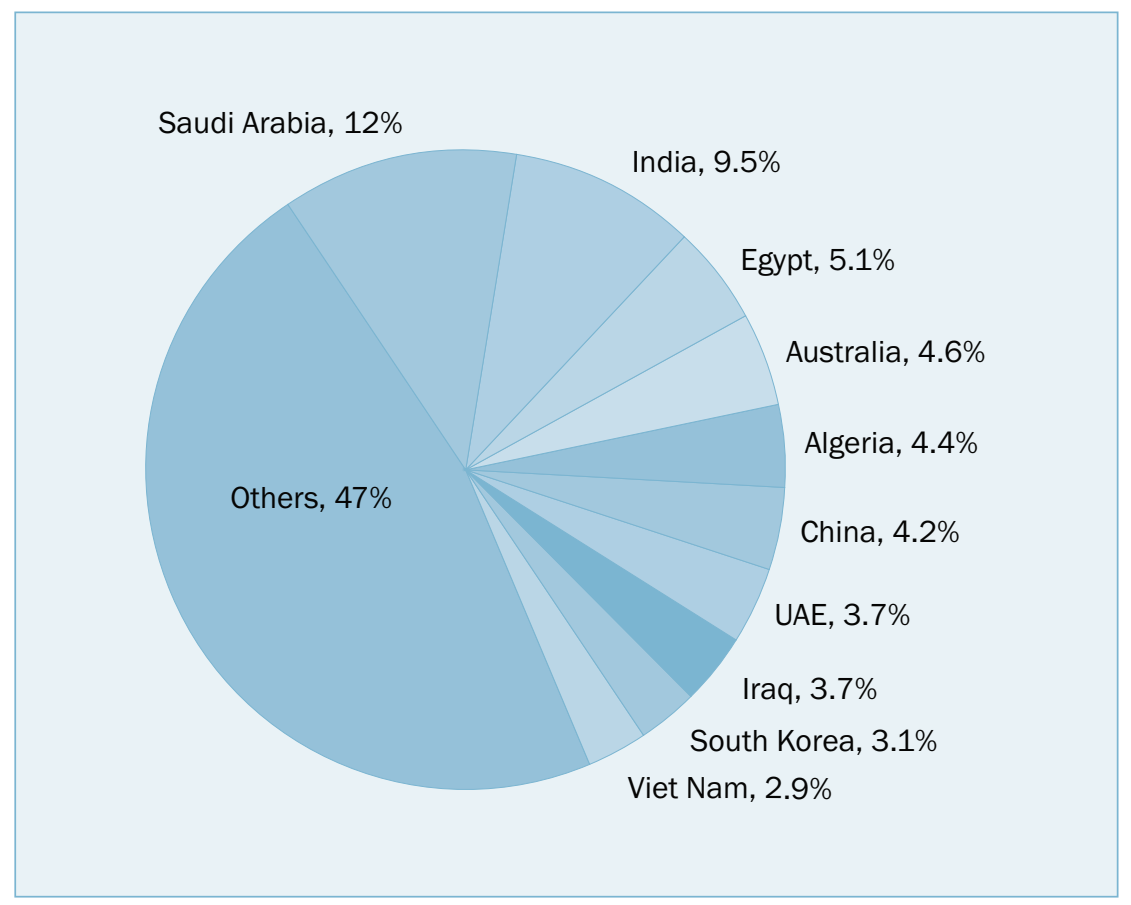

Figure 4. Global share of major arms imports by the 10 largest importers, 2014-18 Source: SIPRI Arms Transfers Database, Mar. 2019.

Brazil was the 23rd largest arms exporter in 2014-18, compared with 13th position in 1984-88 when Brazilian arms exports reached their peak.

\section{THE IMPORTERS, 2014-18}

SIPRI has identified 155 countries as importers of major arms in 2014-18. The top five arms importers-Saudi Arabia, India, Egypt, Australia and Algeria-accounted for 35 per cent of total arms imports in 2014-18 (see figure 4 and table 2). Of these, Saudi Arabia and India were among the top five importers in both 2009-13 and 2014-18. At the regional level, Asia and Oceania accounted for 40 per cent of imports in 2014-18, followed by the Middle East, Europe, Africa and the Americas (see figure 5).

\section{Africa}

Between 2009-13 and 2014-18 arms imports by African states decreased by 6.5 per cent. Algeria accounted for 56 per cent of African arms imports, Morocco for 15 per cent and Nigeria for 4.8 per cent. The four countries in North Africa (Algeria, Libya, Morocco and Tunisia) accounted for 75 per cent of African arms imports. Their arms imports increased by 20 per cent between 2009-13 and 2014-18.

States in sub-Saharan Africa received 25 per cent of total African imports in 2014-18. Their arms imports decreased by 45 per cent between 2009-13 and 2014-18. The top five arms importers in sub-Saharan Africa were Nigeria, Angola, Sudan, Cameroon and Senegal. Together, they accounted for 56 per cent of arms imports to the subregion. 


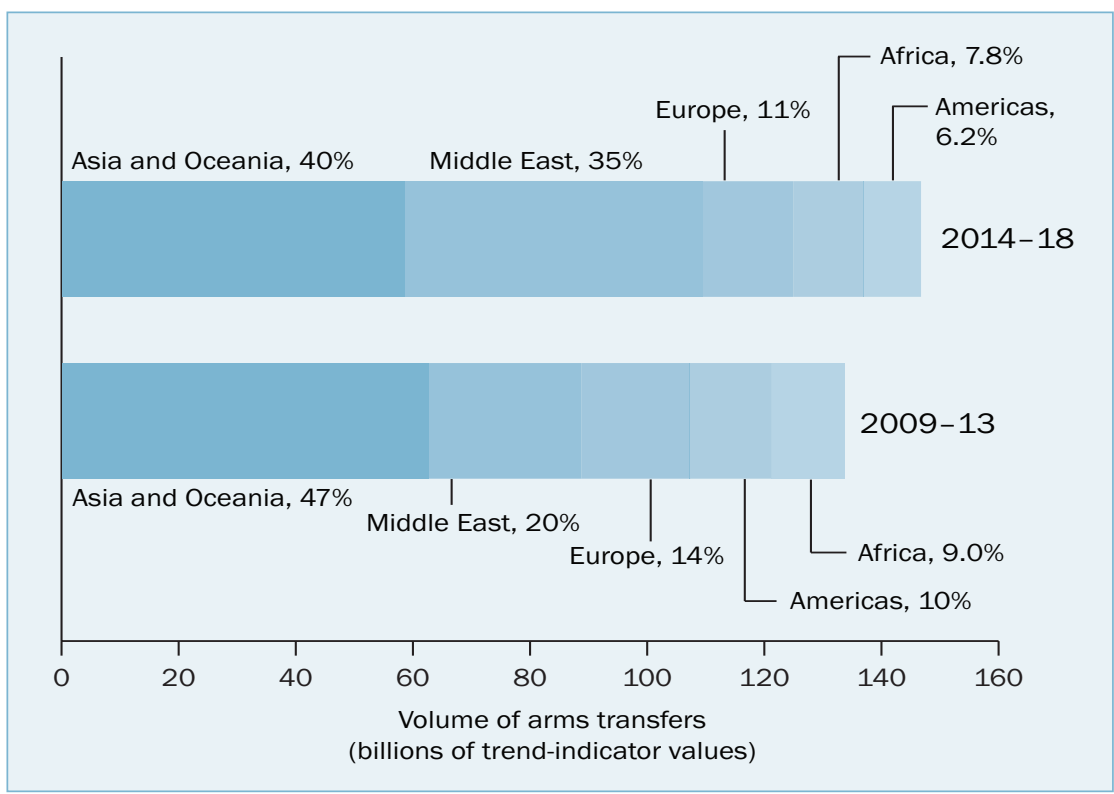

Figure 5. The importers of major arms, by region, 2014-18 and 2009-13, per cent of global share

Note: The SIPRI trend-indicator value (TIV) is a measure of the volume of international transfers of major weapons. The method used to calculate the SIPRI TIV is described on the Arms Transfers Database web page.

Source: SIPRI Arms Transfers Database, Mar. 2019.

\section{Supplier competition in Africa}

In 2014-18 Russia accounted for 49 per cent of total arms imports to North Africa, the USA for 15 per cent, China for 10 per cent, France for 7.8 per cent and Germany for 7.7 per cent. Russia accounted for 66 per cent of Algerian arms imports in 2014-18, compared with 90 per cent in 2009-13. Algeria's other chief arms suppliers in 2014-18 were China (13 per cent) and Germany (10 per cent). The USA (62 per cent) and France (36 per cent) were the main suppliers of arms to Morocco in 2014-18.

Russia accounted for 28 per cent of arms exports to sub-Saharan Africa in 2014-18, China for 24 per cent, Ukraine for 8.3 per cent, the USA for 7.1 per cent and France for 6.1 per cent. In 2009-13 Ukraine was the largest supplier to sub-Saharan Africa; however, its arms exports to the region fell by 79 per cent between 2009-13 and 2014-18.

Nigeria, the largest arms importer in sub-Saharan Africa in 2014-18, received 35 per cent of its arms imports from Russia, 21 per cent from China and 15 per cent from the USA.

\section{G5 Sahel Joint Force}

Although many states in sub-Saharan Africa are affected by armed conflict and some receive foreign military aid, the volume of major arms imported by those states is relatively small. This is illustrated by the case of Burkina Faso, Chad, Mali, Mauritania and Niger, which in 2017 created the Group of Five for the Sahel (G5 Sahel) Joint Force to undertake collective military operations against militant groups, such as Boko Haram. In 2014-18 the combined arms imports of the G5 Sahel states accounted for 0.2 per cent of the global total. In that period they received 26 military aircraft-which included 5 light combat aircraft and 2 combat helicopters-and 179 light armoured vehicles.

\section{Central America and the Caribbean, and South America}

Imports of major arms by states in Central America and the Caribbean grew by 49 per cent between 2009-13 and 2014-18. By contrast, arms imports by South American states fell by 51 per cent between the two periods. Together, the two subregions accounted for 3.4 per cent of total global arms imports in 2014-18. The USA was the main exporter to both subregions: in 2014-18 it accounted for 17 per cent of arms imports by states in South America and 47 per cent by states in Central America and the Caribbean. France (13 per cent) and Germany (9.7 per cent) were the other main suppliers to 
South America in the period. The Netherlands (16 per cent) was the second largest supplier of arms to Central America and the Caribbean in 2014-18.

Mexico accounted for 72 per cent of arms imports to Central America and the Caribbean in 2014-18. Its arms imports increased by 40 per cent between 2009-13 and 2014-18, mainly due to the Mexican military's involvement in internal operations against drug cartels.

Brazil accounted for 27 per cent of South American arms imports in 2014-18. Brazilian arms imports decreased by 28 per cent between 2009-13 and 2014-18. Arms imports by Venezuela, which was the largest arms importer in South America in 2009-13, fell by 83 per cent between the two periods. The decrease coincided with a severe economic crisis in the country.

\section{Asia and Oceania}

Arms imports by states in Asia and Oceania decreased by 6.7 per cent between 2009-13 and 2014-18. States in the region received 40 per cent of global arms imports in 2014-18, compared with 47 per cent in 2009-13. Of the 10 largest importers in 2014-18, half were in Asia and Oceania: India, Australia, China, South Korea and Viet Nam. Russia accounted for 31 per cent of arms exports to the region, the USA for 27 per cent and China for 9.0 per cent.

\section{Australia}

Due to its heightened perception of threats in the Asia-Pacific region, Australia has embarked on major military procurement programmes. As a result, its arms imports increased by 37 per cent between 2009-13 and 2014-18, to the highest level since 1950. In 2014-18 Australia was the world's fourth largest arms importer and accounted for 4.6 per cent of the global total. All armed services have received new major arms in 2014-18, but the main focus has been on aircraft and ships. Deliveries of F-35 combat aircraft and antisubmarine warfare aircraft from the USA made up 53 per cent of Australian arms imports in 2014-18, while ships from Spain accounted for 29 per cent. Large deliveries for additional aircraft and ships are outstanding.

\section{South Asia}

Despite the long-standing conflict between India and Pakistan, arms imports decreased for both countries in 2014-18 compared with 2009-13.

India was the world's second largest importer of major arms in 2014-18 and accounted for 9.5 per cent of the global total. Its imports decreased by 24 per cent between 2009-13 and 2014-18, partly due to delays in deliveries of arms produced under licence from foreign suppliers, such as combat aircraft ordered from Russia in 2001 and submarines ordered from France in 2008. Russia accounted for 58 per cent of Indian arms imports in 2014-18, compared with 76 per cent in 2009-13. Israel, the USA and France all increased their arms exports to India in 2014-18.

Pakistan's arms imports decreased by 39 per cent between 2009-13 and 2014-18. The USA has become increasingly reluctant to provide military aid or sell arms to Pakistan: US arms exports to Pakistan fell by 81 per cent between 2009-13 and 2014-18. Pakistan has instead turned to other suppliers. For example, in 2018 it ordered 4 frigates and 30 combat helicopters from Turkey. 
Box 2. Transfers of unmanned combat aerial vehicles

The number of countries that import and use unmanned combat aerial vehicles (UCAVs)-which are remotely controlled armed aircraft often referred to as armed drones-continued to increase in 2014-18. There is widespread discussion about the impact of UCAV proliferation on peace and security.

China has become the primary exporter of UCAVs. Whereas China exported 10 UCAVs to 2 countries in 2009-13, in 2014-18 it exported 153 to 13 countries - 5 of which are in the Middle East: Egypt, Iraq, Jordan, Saudi Arabia and the United Arab Emirates (UAE). In contrast, the United States delivered three UCAVs in 2009-13 and five in 2014-18. In both periods all the deliveries were to the United Kingdom. Iran delivered 10 UCAVs to Syria in 2014-18, while the UAE delivered 2 to Algeria.

Despite the rise in exports of UCAVs in 2014-18, transfers of such systems accounted for less than 0.4 per cent of total arms transfers in the period.

\section{China}

Despite the rapid development of its indigenous arms-producing capabilities in recent years, China was the world's sixth largest arms importer in 2014-18 and accounted for 4.2 per cent of the global total. Its arms imports decreased by 7.0 per cent between 2009-13 and 2014-18. Russia accounted for 70 per cent of Chinese arms imports in 2014-18. China remains reliant on imports for certain arms technologies such as engines for combat aircraft and large ships as well as long-range air and missile defence systems. Its own arms industry has yet to develop the technological capability to match Russian suppliers in these fields.

\section{Europe}

Imports by states in Europe decreased by 13 per cent between 2009-13 and 2014-18. The fall is partly attributable to the long-term effects of the global economic crisis that started around 2008, which caused many countries in Europe to scale down arms procurement. European countries accounted for 11 per cent of total global imports in 2014-18. Although many of the larger European countries have sizable arms industries, they all continue to import arms. However, by 2018 Russia no longer imported major arms and had no outstanding orders from foreign suppliers. Before 2014, Russia had been importing arms from Ukraine and had started importing arms from other European countries. The Russian annexation of Crimea in 2014 ended these arms trade relations.

Over the years, some EU member states have called for increased cooperation at the European level on the development of arms. Member states have also been encouraged to source the procurement of such arms from within the EU. However, in 2014-18 the USA accounted for 41 per cent of imports of major arms by EU members states and 12 per cent came from other non-EU states. The USA will remain a major supplier to EU member states in the coming years, largely due to outstanding deliveries of a total of 296 F-35 combat aircraft to Belgium, Denmark, Italy, the Netherlands and the UK. The competition between EU and US suppliers continued in 2018: for example, rather than choosing alternatives available from EU member states, Belgium and Slovakia decided to procure US combat aircraft and the UK ordered US anti-submarine warfare aircraft. 


\section{Central and Northern Europe}

Although arms imports to Europe decreased overall in 2014-18, many states in the region-particularly in Central and Northern European countries where there are growing tensions with Russia-have implemented major military procurement programmes since 2014. Norway ordered five anti-submarine warfare aircraft from the USA and four submarines from Germany in 2014-18. It also received the first 16 of a total of 52 F-35 combat aircraft ordered from the USA in 2008.

In 2018 Poland and Romania ordered 30 and 54 short-range ballistic missiles from the USA, respectively. The Polish order was in addition to 138 air-launched cruise missiles ordered from the USA in 2015-16. Poland, Romania and Sweden ordered US air and missile defence systems in 2018.

Ukraine's arms imports were limited in 2014-18, despite the ongoing conflict there, which began in 2014.

\section{The Middle East}

Arms imports by states in the Middle East increased by 87 per cent between 2009-13 and 2014-18. Four of the world's top 10 arms-importing countries in 2014-18 were in the Middle East: Saudi Arabia, which received 33 per cent of arms transfers to the region, Egypt (15 per cent), the United Arab Emirates (UAE; 11 per cent) and Iraq (11 per cent). The USA supplied 54 per cent of total arms transfers to the region, Russia 9.6 per cent and France 8.6 per cent.

\section{The Gulf region}

Arms imports by some Arab states of the Gulf rose sharply between 2009-13 and 2014-18. Among the key reasons behind these increases were the mutual distrust between Iran on the one hand and Saudi Arabia and the UAE on the other; the war in Yemen, which began in 2015; and since mid-2017 the hostile relations between Qatar on the one side and Saudi Arabia and the UAE on the other.

Arms imports by Saudi Arabia increased by 192 per cent between 2009-13 and 2014-18, making it the world's largest arms importer in 2014-18. The USA supplied 68 per cent of Saudi Arabian arms imports. Arms deliveries to Saudi Arabia in 2014-18 included 56 combat aircraft from the USA and 38 from the UK. In both cases, the aircraft were equipped with cruise missiles and other guided weapons. Planned deliveries for 2019-23 include 98 combat aircraft, 7 missile defence systems and 83 tanks from the USA; 737 armoured vehicles from Canada; 5 frigates from Spain; and short-range ballistic missiles from Ukraine.

In 2014-18 the UAE was the seventh largest arms importer in the world. The USA accounted for 64 per cent of arms imports by the UAE. Deliveries in 2014-18 included 5 missile defence systems, 124 short-range ballistic missiles and 1671 armoured personnel carriers from the USA, and 3 corvettes from France. Some of the armoured vehicles were subsequently supplied by the UAE to militias in Yemen.

Qatari arms imports increased by 225 per cent between 2009-13 and 2014-18. The USA accounted for 65 per cent of Qatari arms imports in 2014-18. Qatar also imported smaller volumes of arms from other suppliers, including tanks from Germany, combat aircraft from France, short-range ballistic 
SIPRI is an independent international institute dedicated to research into conflict, armaments, arms control and disarmament. Established in 1966, SIPRI provides data, analysis and recommendations, based on open sources, to policymakers, researchers, media and the interested public.

\section{GOVERNING BOARD}

Ambassador Jan Eliasson, Chair (Sweden)

Dr Dewi Fortuna Anwar (Indonesia)

Dr Vladimir Baranovsky (Russia)

Ambassador Lakhdar Brahimi (Algeria)

Espen Barth Eide (Norway) Jean-Marie Guéhenno (France)

Dr Radha Kumar (India)

Dr Patricia Lewis (Ireland/ United Kingdom)

Dr Jessica Tuchman Mathews (United States)

\section{DIRECTOR}

Dan Smith (United Kingdom) missiles from China and short-range air defence systems from Russia. Planned deliveries to Qatar for 2019-23 include 93 combat aircraft (36 from the USA, 33 from France and 24 from the UK) and 4 frigates from Italy.

Iran accounted for 0.9 per cent of arms imports to the Middle East in 2014-18. Since 2010 it has been under a United Nations arms embargo that is scheduled to last until late 2020.

\section{Iraq and Syria}

While conflict raged in both Iraq and Syria in 2014-18, the trends in arms imports by the governments of these countries differed markedly. In 2014-18 Iraq was the 8th largest arms importer, whereas Syria ranked 60th. Iraq received a wide variety of major arms-including combat aircraft and attack helicopters-mainly from the USA and Russia. Its arms imports increased by 139 per cent between 2009-13 and 2014-18. By contrast, Syria's arms imports fell by 87 per cent between the two periods. Whereas in 2009-13 Russia supplied high-value air defence systems and anti-ship missiles to Syria, in 2014-18 it supplied mainly low-value arms such as second-hand armoured vehicles. However, in 2018 Russia delivered three long-range air defence systems to Syria, its first high-value arms export to that country since 2013.

\begin{abstract}
About the SIPRI Arms Transfers Database
From 11 March 2019 the freely accessible SIPRI Arms Transfers Database includes data on arms transfers for 1950-2018, which replaces all previous data on arms transfers published by SIPRI. The database aims to contribute to an understanding of the effects of arms flows on peace, stability and violent conflict. This Fact Sheet is intended to encourage the use of the database for further research, investigations, policymaking and public debate.

The SIPRI Arms Transfers Database is the only public resource that provides consistent information, often estimates, on all international transfers of major arms (including sales, gifts and production under licence) to states, international organizations and non-state groups since 1950. It is accessible on the Arms Transfers Database web page of the SIPRI website.

SIPRI statistical data on arms transfers relates to actual deliveries of major arms. SIPRI measures the volume of international transfers of major arms using a common unit-the trend-indicator value (TIV). The method used to calculate the SIPRI TIV is described on the Arms Transfers Database web page.

As the volume of deliveries can fluctuate significantly year-on-year, SIPRI presents data for five-year periods, giving a more stable measure of trends. Percentage shares presented in this Fact Sheet do not always add up to 100 per cent or to stated totals because of the conventions of rounding.
\end{abstract}

\section{ABOUT THE AUTHORS}

Aude Fleurant (Canada/France) is Programme Director, Pieter D. Wezeman (Netherlands/Sweden) and Siemon T. Wezeman (Netherlands) are Senior Researchers, Nan Tian (China/South Africa) is a Researcher and Alexandra Kuimova (Russia) is a Research Assistant with the SIPRI Arms and Military Expenditure Programme.
STOCKHOLM INTERNATIONAL PEACE RESEARCH INSTITUTE

Signalistgatan 9

SE-169 72 Solna, Sweden

Telephone: +4686559700

Email:sipri@sipri.org

Internet: www.sipri.org 